\title{
Recognition, the Other and Tragic Self-Actualization
}

\author{
ROBERT R. WILLIAMS \\ University of Illinois at Chicago
}

Idealism's doctrine that the subject is active in cognition, that it constitutes itself, its world and others, opens up new regions for philosophical exploration and examination beyond idealism understood narrowly as an epistemological doctrine, and beyond the narrow, confines of so-called subjective idealism. For Hegel, idealism and realism are not opposites ${ }^{1}$. The order of thought and the order of being are different, and yet in their difference identical in principle. Cognition is a self-correcting process in which error is a necessary moment in the discovery and determination of truth ${ }^{2}$. The relation between self and world, self and other, is dialectical; this dialectic is the structure of rationality itself.

For Hegel, the world is both given and constituted, but it is not necessarily given as the self constitutes it or constituted by the self as it is given. Thus the purpose and the task of philosophy is to bring about a reconciliation of the constituting reason that is conscious of itself with the reason that is, or is actual, through cognition of their ultimate accord, ${ }^{3}$ to wit, the rational is actual and the actual is rational. However, the cultural-historical starting point and need of philosophy is not with the accord as a given, but rather with dichotomy, discord, disruption, fragmentation ${ }^{4}$. Although Hegel intends to overcome discord, fragmentation and disunity, and believes that it is possible to find some sort of unity in and reconciliation to the discord, his powerful analyses of cultural fragmentation, social disruption, alienation and tragic conflict remain

1 Hegel, Science of Logic, tr. A. V Miller, 154-5, New York: Humanities Press 1969, 154-5. Hereafter cited SL.

2 Hegel, Phenomenology of Spirit, Miller trans. Oxford University Press, 1977, §18: Only this self-restoring sameness, or this reflection in otherness within itself--not an original or immediate unity as such--is the true. Hereafter PhS. German: Phänomenologie des Geistes, Hrsg. Hoffmeister, Hamburg: Meiner, 1952. Hereafter PhG.

3 Hegel, Encyclopedia Logic, tr. Harris et. Al., Indianapolis: Hackett, 1990, §6. (EL)

4 Hegel, Difference between Fichte's and Schelling's System of Philosophy, tr. H.S. Harris, Albany: SUNY Press, 1977, p. 89. Hereafter cited as Difference. 
important because it is negation that reveals what is at stake for the wholeness of existence. Negation, otherness, finitude, opposition and conflict are aspects of the whole.

Although Hegel is frequently identified as an apologist for modernity, standing in the tradition of Enlightenment and historical progress, such readings underestimate Hegel's criticisms of those optimistic aspects of modernity. An important Rousseau-influenced strand of modernity believes that humanity is good by nature. But Hegel explicitly rejects this, arguing that if it were true, his whole project of reconciliation would be superfluous. ${ }^{5}$

Hegel defends the contrary proposition, the humanity is evil by nature. This proposition points to Hegel's acceptance of the tragic view, that evil coincides with finitude; to be is to be evil. The first form of the human will is desire, and desire is the immersion of spirit in nature, i.e., self-seeking particularity. Immersed in nature, the human being is not what it is supposed to be, for its vocation is to liberate itself from subjection and form institutions of freedom. Desire therefore is a necessary shape, but also the poorest shape of freedom, characterized by egoistic self-seeking as a particular in opposition to others. At this level, conflict between humans is historically inevitable. Hegel agrees with Thomas Hobbes, that the so-called state of nature is a state of conflict and war, and that it is imperative to leave it behind.

Even more important for our purposes is Hegel's agreement with Schelling that human existence and human freedom are tragic. But it is important to understand Schelling's thesis: tragedy measures not the depravity or weaknesss of human freedom, but its potential greatness.

It has often been asked how Greek reason could bear the contradictions of Greek tragedy. A mortal, destined by fate to become a criminal, fights against this fate, and yet he is horribly punished for the crime, which was the work of fate!....The fact that the criminal, who only succumbed to the superior power of fate, was punished all the same - this was the recognition of human freedom, an honor owed to human freedom. It was by allowing its hero to fight against the superior power of fate that Greek tragedy honored freedom....It was a great thought: To willingly endure punishment even for an unavoidable crime, so as to prove one's freedom precisely through the loss of this freedom and perish with a declaration of free will.".6

5 Hegel, Lectures on the Philosophy of Religion Vol 3. tr. Peter C. Hodgon et al., University of California press, 1985, p 296. Hereafter, LPR 3.

6 Schelling, "Philosophical Letters on Dogmatism and Criticism," tr. Fritz Marti, in the Unconditional in Human Knowledge, Lewisburg Pa: Bucknell University Press, 1980, 192-193, cited by Peter Szondi, An Essay on the Tragic, Stanford, California, Stanford University Press 2002, p. 7, Italics mine. 
Tragedy acknowledges, but nevertheless does not fully take the measure of, human freedom. Tragedy fascinates Schelling, as it fascinated Hegel, because tragedy reveals that something great and lofty (human spirit) was destroyed precisely by what should have saved it. ${ }^{7}$ Human freedom is thus imputable. It admits the possibility of both tragic conflict and a reconciliation that may avoid such conflict or point a way beyond it. Both possibilities are presented in recognition.

In the following essay, I intend to focus on the logical moment of finitude, which constitutes the tragic aspect or dimension in Hegel's account of human existence, freedom, recognition and self-realization. Finitude is characterized by negation, disunion, contradiction, opposition and conflict, within the human self and between human selves. But it is also not the whole story. In his Logic Hegel observes that every category may be regarded as definition/determination of the absolute, at least the first and third aspects of every categorical triad. ${ }^{8}$ The second moment is the finite, and the finite is characterized by negation, negative dialectic, conflict, opposition and struggle. Finitude is the developed negation. It stands between the abstract universal that undergoes diremption, and the infinite negation - the negation of the negation - that constitutes both an affirmative dialectic and the absolute itself as reconciliation.

First we take up the issue of the doubling of self-consciousness, against the background of the dialectics of determinacy, the one and the other in the Logic. This doubling establishes the problem and the task of mediated autonomy and mediated self-actualization that drives the struggle for recognition. The acknowledgement that self-actualization is mediated, constitutes the possibility of tragic misrecognition of oneself, of others, and the possibility of tragic conflict. The problem of a mediated self-actualization is that the self is constituted both by its self-relation, or being-for-self, and by its relation to other, or being-forother. The self is a relation of these relations. The task of self-actualization is the proper coordination of these; yet since the other is independent, that coordination is not simply under the control of the self. Since what is supposed to come about can only come about as the joint, undivided action of both, a onesided action is useless. This implies that the human self is vulnerable in its very self-relation because that relation is open to the other and its influence. This means that tragedy is always possible: the self-relation and relation to other, or being-for-self and being-for-other, which are supposed to be compatible, may fall apart, become disrupted, or achieve only tragic conflict.

Finally we turn to an examination of tragic misrecognition, tragic selfcontradiction, which constitute a 'tragic proof' of the vulnerability of mediated

7 Szondi, op. Cit p 9.

8 EL $\S 85$. 
freedom. Underlying Hegel's analyses of tragedy is his view that finitude and determinacy, ultimately the understanding and cognition itself, present tragic aspects. Cognition both gives the wound and the possibility of healing it.

\section{The Intersubjective Doubling of Self-Consciousness}

While desire relates to its objects by consuming them and demonstrating their nullity, Hegel's account of desire is qualified and modified by the possibility of another sort of relation to another sort of object:

"Self-consciousness achieves its satisfaction only in an other selfconsciousness" 9 .

As Hegel observes, the satisfaction of this desire for an other is different from ordinary consumption desire, because the truth of this satisfaction is not the consumption of an object, but rather a doubled reflection, a doubling of self-consciousness. ${ }^{10}$ This desire is intersubjective, which Hegel expresses in the abrupt remark: there is a self-consciousness for a self-consciousness, and proceeds to analyze this as a doubling. ${ }^{11}$ Hegel expresses this doubling in the opening paragraph of the concept of recognition:

"the self-consciousness is in and for itself, when and through the fact that it is in and for itself for an other: that is, it exists only as recognized" 12 .

This doubling gives rise to the double-sided complexity (Doppelsinnigkeit) of the process of recognition: 1) conflict: self negation, self-othering, self-loss, but also 2) a double-sided return to self in mutually mediated freedom that constitutes spirit as an I that is a We, and a We that is an I. In the latter case

"the first does not have an object before it merely as it exists primarily for desire, but as something that has an independent existence of its own, which therefore it cannot utilize for its own purposes, if that object does not of its own accord do what the first does to it. Thus the movement is simply the double movement of the two self-consciousnesses....Action by one only would be useless because what is supposed to happen can only be brought about by both."13

Here action is indivisibly the action of one as well as the other.

The dialectic of determinate being, the limit, the something (etwas) and the other, provides a logical clarification of the doubling of consciousness.

$9 \mathrm{PhS} \S 175 ; \mathrm{PhG} 139$.

$10 \mathrm{PhS} \S 176 ; \mathrm{PhG} 140$.

11 Miller's translation mistranslates doubling (Verdoppelung) as duplication, thus concealing the very phenomenon that Hegel seeks to describe.

$12 \mathrm{PhS} \S 176,178 ; \mathrm{PhG} 141$.

$13 \mathrm{PhS} \S 182$. 
Hegel shows that becoming is the first category and first concrete thought; but becoming is still a restless indeterminacy. Without determinacy, becoming would be a mere unstable contradiction that vanishes. While all determination is negation; to become determinate is not abstract negation, but a negation which $i s$. Becoming determinate means to undergo a negation and become something. In the category of determinate being the negation is still immediately identical with being, and this negation is what we call limit.

According to Hegel, something is what it is only in and through its limit. Limit is a contradictory concept: one the one hand, it constitutes the reality of determinate being, and on the other hand, it is the negation of determinate being. Thus finitude is contradictory, both in the sense of an immanent contradiction and in the sense of an opposition between determinate being (something) and its other. As self contradictory, finitude is subject to alteration and alteration manifests its inner nature as transitory and mortal.

"Thus otherness is not something indifferent outside of it, but its own moment. In virtue of its quality, something is finite and alterable." 14

As Hegel famously puts it in the Science of Logic:

Finite things are, but their relation to themselves is that they are negatively selfrelated and in this very self-relation send themselves beyond themselves, beyond their being....The finite not only alters...but it ceases to be; and its ceasing to be is not merely a possibility, so that it could be without ceasing to be, but the being as such of finite things is to have the germ of decease as their being-within-self: the hour of their birth is the hour of their death ${ }^{15}$.

Thus finitude is self-contradictory, and the fate of such self-contradictory nullity is metaphysically tragic. In anguish finite freedom senses its potential imminent doom.

Determinate being presupposes and depends on an other to render it determinate by limiting it. The limit is not an abstract nothing, but a nothing which $i s$, which we call an other. The other is not simply an abstract negation, but an affirmative that is inseparable from the one. This affirmative otherness - the inseparability of the one and the other-corresponds to the intersubjective doubling of self-consciousness in the Phenomenology. Hegel expresses the immediate connection (doubling) between something and other thus:

"Given the something, we immediately look for the other, because we know that there is not only the one something, but also the other. Nor again is the other of such a sort that we can think the something without the other. Rather the something 
is in itself the other of itself, and in its other the limit of the something becomes objective to it" 16 .

Hegel points out that when we first hear the expression something other or something else, we assume that the something, taken separately is "only" the something, and that the other is added externally to it. But this is not the case: the something includes its limit and its limit is both itself and the other of itself. Yet if we now ask for the difference between the something and the other, it appears that both are the same, and this identity is expressed in Latin by the aliud...aliud: the one and the other. ${ }^{17}$

One result of this is a contradiction or collision between the one and the other: each is what the other is not, and yet both are also the same. As Hegel shows later, this view can develop into atomism. ${ }^{18}$ Atomism is not just a theory in physics; it is also view of community in which individuals remain external to each other and can be united only through force and compulsion. This view of the state as essentially coercion is expressed in Fichte's Foundations of Natural Law. ${ }^{19}$ Hegel believes that Fichte constitutes community as tyranny ${ }^{20}$ anticipating Sartre's notorious dictum that Hell is other people. Clearly such views are tragic: the community on which free beings depend for protection of their freedom, subverts and cancels their freedom.

Note that Hegel's discussion here shows the impossibility of separating internal relations (the immanent self-contradiction of the something) from the external relations and vice-versa. The other makes the self's limit objective to the self. This corresponds roughly to Hegel's account of the dialectic of self and other in the process of recognition: what is done to other is done to the self, and what is done to the other, the other must do to itself: the master cannot enslave the slave unless the slave constitutes himself as a slave out of the fear of death invoked by the master. Such a correlation between self and its limit mediated by the other is exploited by the master in order to keep the slave in thrall. Such coercion of a free being under the threat of death is an outrage, a practice that, as Hegel says, reflects a time in which wrong still counted as right. ${ }^{21}$

\section{RECOGNITION}

The starting point of Hegel's analysis of recognition is the collision between self and other, the zero point of their mediation. The account of recognition

16 EL $\S 92 \mathrm{Z}$.

17 Ibid.

18 EL $\$ 98$

19 Fichte, Grundlage des Naturrecht (1796); ET Foundations of Natural Law, Michael Bauer, Cambridge University Press, 2001.

20 Hegel, Difference, 144-150.

21 Hegel, Philosophy of Right §57R, tr. Nisbet, Cambridge University Press, 1990. 
begins at a pre-ethical level of indeterminacy and mutual externality in which each regards the other with suspicion, as a potential obstacle to be eliminated. The other makes me other to myself, and thus disrupts and rends my own immediate self-relation. The elimination of the other appears to be the only way to restore my immediate certainty and immediate self-relation. The process of recognition proceeds through the life and death struggle, the halfway house of master and slave, and is consummated in mutual recognition. Each phase or Stufe of the process of recognition has ethical significance, ranging from the pre-ethical violence of the life and death struggle of the state of nature, to relations of domination - mastery and servitude - founded on coercion, to the mutual realization of freedom as a social infinite in mutual recognition. Mutual recognition is the consummation of the process, because only in it do

"I find myself in another person; for this other I count for something, who in turn counts for me."22

Hegel begins with an account of the doubling of self-consciousness. This doubling (Verdoppelung) is both an intrasubjective doubling within consciousness as well an intersubjective doubling 'between' consciousnesses. These must be distinguished and yet they are not separate. They are tied together in correlation. On the one hand, self-relation is more than a simple internalization of the other-relation. The self's understanding of itself and its way of relating to itself also conditions and shapes the way in which it relates to others. On the other hand, the self in its own self-relation is not absolutely autonomous, but is open to and dependent on other. Its self-identity is shaped, both positively and negatively by the other. Self-identity is thus alterable vis a vis the other.

Since the self-relation is open to and dependent on the other, the self is vulnerable to the other and to misrecognition. ${ }^{23}$ For example, the initial encounter with the other divides the self. This division is experienced as self-alteration and self-loss. The altered, divided self seeks to reconstitute itself as a whole. But it can do so only if the challenge created by the presence of the other and the problem of self-alteration can be overcome.

The presence of the other immediately alters the self-relation: it expells the self from its immediate narcissistic indeterminacy to consciousness of itself as a particular. The presence of the other reveals the self to be not only a particular,

22 Hegel, Philosophy of Right $\$ 158 \mathrm{Z}$.

23 According to Stephen Houlgate, Hegel does not privilege identity over difference as is frequently maintained. "Far from arguing that everything absorbs (or tries to absorb) what is external and other into itself Hegel maintains that everything within itself is open to the outside." Houlgate, The Opening of Hegel's Logic, West Lafayette: Purdue University Press, 2006, p.350. "For Hegel being other-related and open to the influence of others is built logically into the structure of something (Etwas) as such." 354. 
but a particular in opposition to another particular. Prior to encounter, the self is indeterminate, potentially universal, and yet parochial and exclusive. In the encounter its parochialism becomes explicit. The other by his mere presence, constitutes an unmediated opposition; this opposition effects a transition of the self from abstract, immediate indeterminacy to determinacy. To be determinate is to be limited by and dependent on another. This has been negatively expressed by Sar - tre in a classical formulation: The other means that my transcendence is transcended. I am no longer master of the situation. Through the presence of other, I come to realize that I am a transcendence that has been transcended, that I am my body, that through the other I "fall" into the world as an object among other objects. ${ }^{24}$ This situation is intolerable. It is an existential contradiction, and, as Hegel notes, contradiction "moves the world". 25

According to Hegel, there are three possible types of 'solution' to the challenge posed by the other.

1. Eliminate the other, thereby attempting to restore the original immediacy and subjective certainty. But to eliminate the other means not only that I must risk my own life, but also that the other is taken to be only a negative limit to my freedom and not its condition. Moreover, to eliminate the other is self-defeating because the self needs and depends on the other's recognition. This 'solution' is obviously pre-recognitive and pre-ethical.

2. Assimilate and dominate the other. This implies asymmetry, e.g., one is recognized but does not recognize in return, e.g., master, while the other recognizes but is not recognized in turn, i.e., slave. The slave fears death; in thrall to his existence and desperate to preserve it, the slave surrenders his claim to recognition as free. He preserves his life, but in the mode of thinghood, of being a mere receptacle for the ends and wishes of the master. The master preserves his independence, but it is an independence tied to coercion and domination, and thus resolves one contradiction only to fall into another.

Neither elimination of the other nor its assimilation solves the problem of conflict, because what is needed is the other's free uncoerced recognition, and both 1 and 2 mean that such recognition is impossible. In both cases desire remains an exclusive, self-seeking particular. Although master and slave constitute a relation, owning to its asymmetry, their relation has to be founded on coercion and the threat of death. In spite of their relation, they remain external. They fall into and perpetuate the false infinity of domination.

24 See Jean-Paul Sartre, Being and Nothingness, tr. Hazel Barnes, Philosophical Library: New York, 1956.

25 EL §119 Zusatz 2. 
There is an alternative,

3. let the other be. This is not indifference. Rather letting be is the beginning of a noncoercive affirmative mutuality in which both are dependent and yet independent within this dependence. Each limits, conditions and recognizes the other, such that together they jointly constitute a free whole or totality. In such a totality, humans are united inwardly through the mutual mediation of their freedom, rather than merely externally (as in the case of need). Each is both mediator for the other and an 'extreme' whose self-relation is mediated by the other. Uncoerced, free reciprocal mediation opens the way to an affirmative mutuality in which the I becomes a We. Only here does the other count, i.e., possess affirmative and normative significance as both a condition of and a freely acknowledged limit to my freedom. In such a free totality, dependence is not the antithesis of freedom but its condition. Freedom assumes the shape of union, mutual participation and membership,i.e., ethical life.

\section{Recognition: the 1825 Lectures on Philosophy of Spirit}

The 1807 Phenomenology presents variations on the theme of master and slave. But master/slave do not constitute, much less exhaust the possibilities of recognition. Hegel develops the affirmative possibilities of recognition in his Encyclopedia Philosophy of Spirit and the Philosophy of Right. However, a useful account recognition is also found in the virtually unknown 1825 Lectures on the Philosophy of Spirit. ${ }^{26}$

We noted above that the intrasubjective self-relation conditions the intersubjective relation to other, and the relation to other conditions the self's relation to itself. The intrasubjective self-relation and the intersubjective relation to other are correlative. How the self understands itself conditions its relations to others. The self that thinks of itself as merely the indeterminate immediate remains at the level of desire and need, and sees others as external threats. Moreover,

"The unfree man... makes slaves of others. The man who is inherently free lets the others be free." 27

26 This the Griesheim transcription of Hegel's 1825 Lectures on Philosophy of Spirit. It has been reprinted and translated by M.J. Petry in Hegel's Philosophy of Spirit Vol. 3 appendix, and also as a separate text, G.W.F. Hegel:The Berlin Phenomenology, Dordrecht: D. Reidel 1981. All references are to the Berlin Phenomenology. Hereafter cited as BPhG.

27 Hegel, Lectures on the Philosophy of Spirit 1827, tr. Robert R. Williams, Oxford University Press 2007, p. 163; German: Vorlesungen ueber die Philosophie des Geistes, Meiner, 1994, 136. 
Conversely, the relation to other shapes and conditions self-identity and self-relation. For example, the slave's self-identity and its world are shaken and dissolve under the threat of death, the absolute master. That dissolution is why the mentality of the slave becomes a receptacle for and interiorizes the views and values of the master. The truth of mastery and coercion is seen in the false consciousness of the slave. The self's relation to itself stands in correlation to the recognition, or the mis-recognition, it receives from the other. This correlation breaks down any abstract separation between 'inner' and 'outer'.

Hegel's 1825 Lectures on the Philosophy of Spirit are important for clarifying these correlations. ${ }^{28}$ First, there are logical conditions of mutual recognition: Hegel shows that until the self is capable of grasping the contrast between universal and particular, it is trapped in an abstract indeterminate immediacy, an either/or posture, the opposition and contradiction of finitude, and is incapable of mutual recognition which depends on the universal, the possibility of a 'We'. Second the text contrasts the reciprocal recognition constitutive of ethical life with the unequal coercive recognition constitutive of master and slave. Master/slave does not exhaust the meaning of recognition, or exhibit its normative actualization. For Hegel the truth of intersubjectivity is not conflict, but mutual recognition and freedom: being at home with oneself in one's other. Third, the text shows how Hegel understands self-recognition in other to be mediated self-actualization. This mediated self-actualization clarifies in turn the concept of spirit as universal consciousness.

Hegel begins by noting that in the account of the life and death struggle and master/slave, the selves conceive themselves and the other as immediate, exclusive singularities:

"all of this lacks the determination and condition of universality and remains in the form of immediate singularity. At this level of self-understanding it is still the case that if I recognize another as free, I lose my freedom" 29 .

When the self thinks of itself as an immediate singularity - as the "I am I"- recognizing the other appears to be a loss of freedom. Hegel notes that under the conditions of immediacy, "Desire relates itself only to itself..." ${ }^{30} \mathrm{In}$ desire,

"the immediate singularity of my self-consciousness and my freedom are not yet separated. Consequently I am unable to surrender anything of my particularity without giving up my independence..... have not yet renounced this [purely self-

$28 \mathrm{BPhG}$. I have corrected the translation. On the concept of correlation cf.Erroll E. Harris. An Interpretation of the Logic of Hegel, University Press of America, 1983, 184ff.

29 BPhG 74-77.

30 BPhG 76-77. 
regarding, self-seeking] particularity, I have not yet distinguished it from myself, not yet discarded it, have not yet raised the self-consciousness of my freedom to universal self-consciousness." 31

In desire, consciousness has not yet distinguished its particularity and universality, but remains on the pre-or sub-ethical level. ${ }^{32}$

Hegel observes that

"the self-consciousness here is still immediate and singular, for it has not yet abstracted from its own singularity; here desire still rules and the property others possess is taken by the self-consciousness to be a limitation on its freedom.... the standpoint is that as a self I am still an immediate singular that has not yet renounced its particularity and thus I determine myself according to my desire... which refers only to itself..."33

\section{Consequently under these conditions and presuppositions}

"there can be no recognition of the one by the other. Both assert their [unqualified] independence. What is more, each is unwilling to recognize the other in itself on account of its own parochial freedom and it cannot be recognized by the others on account of the way in which it is for the others." 34

As long as the selves understand themselves in this atomistic way, mutual recognition cannot occur. This has tragic consequences ${ }^{35}$.

\section{Tragic Recognition}

We have seen that for Hegel recognition involves a correlation between the intrasubjective self-relation and the intersubjective relation being-for-other. How the self thinks itself, shapes how it recognizes and relates to the other, and how the other recognizes the self shapes, negative or affirmatively, its selfrelation and self-identity. These correlations or their absence, are inherent in Hegel's account of tragedy. Hegel boasted that he had read all the ancient Greek

31 BPhG 76-77.

32 The practices of comporting oneself 'universally', i.e., acting out of mutual acknowledgment and recognition of others, and claiming rights for oneself only insofar as these can be claimed by any other and vice-versa, have not yet been imagined, much less achieved.

33 BPhG 78-77. My italics.

$34 \mathrm{BPhG}$ 80-81. My italics. The self in its immediacy, as pure I = I, is immediate and abstract self-relation. Inability to recognize the other in oneself is also a feature of tragic blindness. Hegel employs this feature in his discussion of Antigone; Antigone and Creon do not recognize the claims each makes on behalf of the family and state, with tragic results.

35 Mutual recognition requires that this immediacy be negated, mediated and articulated. Through the process of recognition the self raises itself to the universal and becomes capable of being a member of an ethical community and totality. 
tragedies; his discussions stimulated more modern interest in these than any philosopher since Aristotle, and among his favorites were Sophocles' Oedipus the King and Antigone. Both of these tragedies illustrate Hegel's general thesis concerning tragedy, to wit, that the essence of tragedy is conflict, not a moral conflict between right and wrong, but rather conflict between right and right. Hegel writes:

The original essence of tragedy consists...in the fact that within such a conflict, each of the opposed sides, if taken by itself has justification; [but] each can establish the true and positive content of its own aim and character only by denying and infringing the equally justified power of the other. The result is that in its ethical life and because of it, each is nevertheless involved in guilt. ${ }^{36}$

But how is a conflict between legitimate concerns and rights possible? One answer is suggested by Hegel's analysis of Oedipus. In his analysis, Hegel presents a deeper exploration of the intrasubjective self-relation, namely, qualified as a false consciousness. Oedipus is caught in the opposition between the known and the unknown ${ }^{37}$ and between knowing and not-knowing. ${ }^{38}$

The result is that Oedipus does not know who he is, and when he acts, he is blinded by his false certainty and oblivious to the very possibilities he seeks to avoid. ${ }^{39}$ Oedipus has committed parricide and incest,

"yet he has been involved in these crimes without either knowing or willing them." 40

\section{Hegel points out that}

The doer finds himself...in the antithesis of knowing and not-knowing. He takes his purpose from his character...but on account of the determinateness of his character he knows only the one power of [ethical] substance, the other remaining concealed from him. The present reality is therefore, one thing in itself, and another matter entirely for consciousness. The upper and lower law come to signify in this connection [respectively] the power that knows and reveals itself to consciousness, and the power that conceals and lies in ambush. ${ }^{41}$

36 Hegel, Aesthetics: Lectures on Fine Art, Vol 2, tr. TM Knox, Oxford University Press, 1975, 1196. I have modified the translation. Hereafter cited Aesthetics II.

$37 \mathrm{PhS} \$ 467$.

38 In his reading of Oedipus, Hegel introduces not only the concept of false consciousness, but the unconscious (unbewusst). For a useful discussion of Hegel's concept of the unconscious and a comparison with Freud and Nietzsche, see Daniel Berthold-Bond, Hegel's Theory of Madness, Albany: SUNY Press, 1995.

$39 \mathrm{PhS} \$ 467$.

40 Aesthetics II 1214.

$41 \mathrm{PhS} \$ 737$ Italics mine. 
Oedipus discovers his crimes only after his deed: Actuality holds within it another aspect that was concealed from Oedipus: the son did not recognize his father in the man who wronged him and whom he slew, nor his mother in the queen whom he makes his wife.

"In this way a power which shuns the light of day ensnares the ethical selfconsciousness, a power which breaks forth only after the deed is done, and seizes the doer in the act." ${ }^{42}$

The true significance of Oedipus' deed is that that which was hidden from him, that truth about himself to which he was oblivious, can and will destroy him. Oedipus discovers that his ethical rectitude and knowing are both onesided, and that he has seized upon only one of the powers of ethical substance while being blind to the other.

"In following the god that knows, [he] really got hold of what was not revealed, and pays the penalty for trusting a knowledge whose ambiguity becomes explicit..." 43

The action of the play is the inversion of the known into its opposite. Oedipus' lucid, rational self-assurance and certainty are revealed and confirmed as blindness and self-forgetfulness. ${ }^{44}$ Oedipus discovers that he is not who he thought he was, and the recognition of his true identity is unbearable.

In the Antigone, the situation is different. Antigone is not, like Oedipus, in false consciousness; she knowingly violates Creon's edict. Her pathos is her family ties and ethical obligation to bury her dead brother Polynices. Thus she defies Creon's edict forbidding such honor and burial to those who died when they took up arms against the regime of Thebes. In Hegel's view, Creon's edict is legitimate but unwise, because it brings the state into conflict and opposition to the family. Creon and Antigone, in pursuing their ethical pathos - the state and the family-plunge these otherwise compatible institutions into conflict. Each pursues a legitimate right, but in a one-sided way that refuses to recognize the legitimacy and validity of the other. As Hegel observes,

"the opposition between them appears [merely] as an unfortunate collision of duty with a reality that possesses no rights of its own.... Since it sees right only on one side and wrong on the other, that consciousness which belongs to the divine law [Antigone] sees in the other side [Creon] only the violence of human caprice, while that consciousness which holds to human law [Creon] sees in the other [Antigone] only the self-will and disobedience of the individual who insists on 
being her own authority." 45

According to Hegel, tragic conflict is not only a collision between legitimate substantial interests, it also plunges the characters themselves into selfcontradiction. For example, Antigone and Creon are unwilling to recognize each other, and the other in themselves. Antigone sees in Creon's edict against burying rebels who take up arms against the city only an illegitimate act. Creon sees in Antigone's burial of her brother Polynices only a stubborn, irrational woman out to undermine his authority. Each character, by single-mindedly pursuing one legitimate substantial interest, collides with and violates another. Thus each infringes and is ensnared by the power which s/he refuses to recognize.

Hegel points out that Antigone and Creon are caught in the power of what they are resisting and fighting. He observes that they violate what, if they were true to their own values and Sittlichkeit, they should be honoring. Antigone is the daughter of a king, living under the reign of another king, and so she should obey the royal command. Creon is also a father and husband, and thus should have respected the family tie which is Antigone's pathos, and not ordered anything which would prevent its observance.

"So there is something immanent in both Antigone and Creon, which they attack, so that they are gripped and shattered by something intrinsic to their own actual being."46

By failing to recognize and instead attacking the other, each also plunges himself into substantial self-contradiction: s/he repudiates a 'part of himself' which s/he should recognize and honor. Each contradicts himself/herself as well as the other, and in this reciprocal contradiction they bring their downfall upon themselves. Hegel's analysis of the conflict between Antigone and Creon shows that their self-contradiction leads to their destruction. Hegel's reading of the Antigone exhibits and confirms Schelling's thesis that in tragedy something great and noble is destroyed precisely by what should have saved it. Antigone and Creon do not have to persist in their mutually one-sided fixity of will that generates their conflict and their respective self-contradiction. But each is stubborn and unyielding, and through such unyielding fixity of will they are both heroic and self-destructive. This fixity of will is both rational-because each seeks to do what is right - and irrational because in sticking firmly and without compromise to what is right, each necessarily has to infringe another power and right without which s/he cannot live or survive. This observation leads to a concluding remark on tragedy and the understanding. 


\section{The Understanding and Tragic Self-Subversion}

According to Hegel, the essence of tragedy is conflict, a conflict between legitimate, equally justified rights. Tragic conflict is generated by a firm, unyielding adherence to and doing of what is right. This unyielding adherence to the right is a pathos, a passionate self-limitation to a particular cause that isolates it from its context and pursues it to the exclusion of everything else. Such commitment is noble, laudable, admirable, but it is also one-sided and ultimately tragic. Doing the right thing in this one-sided, exclusive way is potentially tragic because it divides a whole, and a whole divided against itself cannot stand. Tragic conflict is a type of negative dialectic; it is generated by the tendency of the understanding towards isolation, abstraction and separation that, pushed to the extreme, produces antinomy and tragic self-subversion.

Yet Hegel does not simply dismiss the understanding as does Jacobi. Jacobi's complaint is that if rational thought--the understanding - is pursued consistently, it leads to ruinous and destructive results. Jacobi is dismissive of the understanding and of thought in general; he believes that showing the understanding to be self-subversive will help him persuade people that a leap of faith is necessary - a leap into immediate knowing. In contrast, Hegel defends the discursive analytical understanding: without it there would be no fixity or determinacy in either theory or practice ${ }^{47}$ In theory, the principles of the understanding are abstract identity and the law of contradiction. In practice, the understanding is crucial to achieving anything great: as Goethe says, someone who wants to do great things has to know how to limit himself. For someone who wants to do everything really wants to do nothing well, and accomplishes little or nothing. Hegel even claims that the self-limiting discursive thought of the understanding corresponds to the goodness of God, i.e., the creation of a world of finite goods. ${ }^{48}$

Nevertheless, although the discursive understanding is essential and important, it

"cannot have the last word. On the contrary, it is finite and more precisely, it is finite such that when pushed to an extreme, it overturns into its opposite." 49

There are two points to be noted concerning this overturning, a negative and an affirmative. First, the negative: Hegel identifies the understanding with negative dialectic, or finitude. Finitude he tells us

"is the most stubborn category of the understanding; negation, constitution and 
limit all reconcile themselves with their other determinate being; and even nothing [reconciles] with being; but finitude is the negation fixed in itself." 50

Persisting in this fixity, the understanding and the determinate conditions it identifies that are essential for life, all become their opposite, i.e., tragic. For such fixity and abstract separation

"is the refusal to let itself be brought affirmatively to its affirmative, to the infinite, and to let itself be united with it. It is therefore posited as inseparable from its nothing and is cut off from all reconciliation.... The understanding persists in this sadness of finitude by making non-being the determination of things and by making it imperishable and absolute." 51

By making finitude, i.e., non-being, the fixed, unalterable determination of things, the understanding blocks and prevents the very mediation and vital processes necessary for both finitude and for life.

"Self-subsistence pushed to the point of the one as being-for-itself, is abstract, formal and destroys itself. It is the supreme, most stubborn error, which takes itself to be the highest truth, manifesting itself in more determinate forms as abstract freedom, pure ego and evil....This self-subsistence is the error of regarding as negative that which is its own essence....Thus it is the negative attitude towards itself which, in seeking to possess its own being, destroys it, and this its act is only manifestation of the futility of this act." 52

In this examination of the negative dialectic of the understanding, Hegel brilliantly expands Schelling's thesis concerning the tragic: to wit, that in tragedy something great and lofty (human spirit) is destroyed precisely by what should have saved it. 53 This "should have saved it" is the silver lining Hegel finds in the dark clouds and spiritual desert of tragedy. It implies not only human imputablity for evil, but also that there is an alternative to tragic self-contradiction, conflict and destruction. The very forces and above all the powers of cognition that lead to tragic conflict, also are capable of correcting and averting it, and transforming tragic outcomes and destruction into something better.

In the Logic, Hegel observes that the understanding not only imparts rigidity and fixity to its determinations that plunges them into conflict and antinomy, the understanding also

"spiritually impregnates them and so sharpens them that just at this extreme point alone they acquire the capability to dissolve themselves and to pass over into their

50 SL 129-130.

51 SL 130.

52 SL 172 Remark: the Unity of the One and the Many.

53 Szondi, op. Cit. p 9. 
opposite." 54

This dissolution and passing over into opposite is the tragic downfall generated by the understanding. It is the wound of spirit.

However, this power of spiritual impregnation that Hegel attributes to the understanding, "belongs properly to the concept," 55 i.e., to reason.

"Therefore the usual practice of separating understanding and reason is, from every point of view, to be rejected....The determinate and abstract concept is... an essential moment of reason; it is form spiritually impregnated, in which the finite, through the universality in which it relates itself to itself, spontaneously catches fire, posits itself as dialectical, and is the beginning of the manifestation of reason." 56

Hegel points to the freedom and creativity of spirit-wherein form "spontaneously catches fire". Spirit is capable of negating the negation, i.e., of transforming the dissolution and destruction wrought of necessity by the understanding into a new beginning in which the negative ceasing-to-be constitutive of finitude, itself ceases to be ${ }^{57}$ Or as Hegel expresses it, cognition both gives the wound and heals it..$^{58}$ The meaning of this healing and reconciliation is another topic for another time ${ }^{59}$.

54 SL 611.

55 Ibid. Italics mine.

56 SL 612. Italics mine.

57 SL 130-131.

58 EL $\$ 24 \mathrm{Z}$.

59 I am completing a group of studies, tentatively titled, Tragedy, Recognition and the Death of God: Studies in Hegel and Nietzsche. 
